\title{
Evaluation of the Effect of the Covid-19 Pandemic on the Education Process of Dentistry Faculties in Turkey: A Survey Study
}

\author{
Belen Sirinoglu Capan ${ }^{1}\left(\mathbb{D}\right.$, Guzide Pelin Sezgin ${ }^{2}$ \\ ${ }^{1}$ Department of Pedodontics, Faculty of Dentistry, Biruni University, Istanbul, Turkey \\ 2Department of Endodontics, Faculty of Dentistry, Biruni University, Istanbul, Turkey \\ Correspondence Author: Guzide Pelin Sezgin \\ E-mail: psezgin@biruni.edu.tr \\ Received: 08.07.2021 Accepted: 31.10 .2021
}

\begin{abstract}
Objective: The aim of this study is to determine the existing changes in the education process in dentistry faculties in Turkey from the spring term of 2020 to the present day and to provide information exchange between universities.

Methods: In total 79 dentistry faculties in Turkey were invited to this survey study. Data were collected between April 15, 2021 and May 1, 2021. In the 32-item questionnaire, questions were asked about the characteristics of the faculties (state or private institution, foundation year) and how they carried out their educational activities (online, face-to-face, etc.) since the beginning of the pandemic. Chi-square test and Fisher's Exact test were used to determine the differences between the groups $(p<0.05)$.

Results: The questionnaire was answered by 67 dentistry faculties (84.8\%). Theoretical education in dentistry faculties continued online at a rate of $71.6 \%$ in all three terms. Preclinical and clinical education, which continued through distance education in the spring of 2020, was carried out mostly face-to-face $(51.6 \%$ preclinical, $88.2 \%$ clinical) in the spring of 2021 . The rate of continuing the theoretical education online $(72.5 \%)$ of public universities in the spring term of 2020 was statistically higher than that of private universities $(70.4 \%)(p<0.05)$. While most of the faculties performed their theoretical (83.6\%) and preclinical (51.5\%) exams online in the spring of 2020, they preferred to conduct the practical exams mostly (47.8\%) face-to-face in the 2021 spring term.
\end{abstract}

Conclusion: During the pandemic process, a hybrid education model was preferred in dentistry faculties in Turkey, in which theoretical courses are offered by distance education and practical courses are provided face-to-face.

Keywords: Covid-19, Dentistry, Distance education

\section{INTRODUCTION}

The World Health Organization declared the Covid-19 disease caused by the SARS-CoV-2 (corona) virus as a pandemic on March 11, 2020 (1). Until today, no clear treatment has been found for Covid-19, and vaccine production studies have begun to be carried out in different countries of the world in order to prevent the pandemic. There are countries in the world that already have intensive vaccination, and currently, individuals over the age of 18 are vaccinated in our country. Since the beginning of the pandemic, various preventive measures, including quarantine processes, have been implemented in most countries in order to break the chain of transmission of the infection. In addition, social life has changed considerably on a global scale due to the pandemic (2).

Along with the quarantine processes, face-to-face education activities at undergraduate and postgraduate level have been greatly interrupted in most countries. In order to manage this process in our country, the Council of Higher Education ( $\mathrm{COHE}$ ) has decided to transition to distance education in the spring term of 2020 (3). Since the quarantine and social isolation times are unpredictable, most universities have turned to alternative education tools in order to continue their education and training activities and have engaged in various researches on this subject (4). In this process, educators around the world had to switch to the distance education model (such as online courses, exams) $(5,6)$. Many dentistry faculties have also faced various difficulties due to the pandemic (7). In a recent study investigating how dentistry faculties in European countries continue their educational activities during the pandemic, $72 \%$ of them are online live videos, $48 \%$ are links to additional online materials, $65 \%$ are online meetings and fewer small-scale 
study groups, social media groups or magazine clubs have been reported (8). However, there is little evidence and study about the real impact of these education models on dental education (9). On the other hand, considering the preclinical and clinical education processes in dentistry faculties, the available alternative options are very few (5).

In the near future, it is foreseen that distance education will be the main ground of education instead of being an alternative or a support tool in face-to-face learning (10). In the literature review, no studies were found on how the dentistry faculties in Turkey carried out their educational activities during the pandemic process. Therefore, the aim of this study is to determine the existing changes in the educational processes in dentistry faculties in Turkey from the spring term of 2020 to the present, and to investigate existing techniques and new perspectives in this field. With this study, information exchange was ensured with dentistry faculties across the country, and it will be possible to be prepared for possible demands for dental education in similar pandemic processes that may be encountered in the future. The hypothesis of this study is that dentistry faculties would prefer a hybrid education model where online education will be provided in theoretical courses and face-to-face education will be provided in preclinical/clinical education.

\section{METHODS}

In order to carry out the study, permission was obtained from the scientific research studies department on COVID-19 in the Scientific Research Platform of the Ministry of Health. Subsequently, this study was accepted by Biruni University Ethics Committee (Date: 09.04.2021 No: 2021/50-21). This research, which was planned as a cross-sectional survey study, was carried out between April 15, 2021 and May 1, 2021. Participation in the study was completely voluntary, and answering the survey questions was interpreted as consent to participate in the study. All dentistry faculties whose educational process started in Turkey were included in the study $(n=79)$. The sample size required for the research consists of 79 dentistry faculties still continuing their education activities in Turkey. For this study, the minimum sample size was 66 according to the $95 \%$ power calculation. The questionnaire, which was prepared using the "Google Forms" application and consisted of 32 questions in total, was sent to all dentistry faculty deans via e-mail. The survey questions are multiple choice and more than one option can be marked separately. The questionnaire form consists of two parts. In the first part, there are questions about the characteristics of the faculties (name, public or private institution, year of establishment). In the second part, detailed questions were asked about how they carried out their educational activities and exams (online, face-to-face, hybrid, video, homework, etc.) since the beginning of the pandemic. In this section, how the theoretical and practical courses as well as clinical applications are carried out were questioned separately. In addition, in this part of the questionnaire, the opinions of the faculty deans were taken about precautions taken in clinics for infection control and extra materials provided, compensation for practical and clinical applications that could not be made during the pandemic period, virtual models related to distance education in practical courses, reliability of online exam results and precautions taken for the reliability of these exams.

\subsection{Statistical Analysis}

IBM SPSS Statistics 22 (IBM SPSS, Turkey) program was used for statistical analysis of the findings obtained in the study. The conformity of the study parameters to the normal distribution was evaluated with the Shapiro Wilks test. When comparing quantitative data, Mann Whitney $U$ test was used to compare parameters that did not show normal distribution. Chi-square test, Fisher's Exact test, Fisher Freeman Halton test and Continuity (Yates) Correction were used to compare qualitative data. Significance was evaluated at the $p<0.05$ level.

\section{RESULTS}

A total of 67 (84.8\%) faculty deans answered the survey questions completely in the 2-week period given for answering the survey. The education period of the faculties participating in the research varies between 1 and 113 years, $59.7 \%$ of them are state universities and $40.3 \%$ are private universities. Approximately $42 \%$ of the universities participating in this study provide education between $0-5$ years, $20.9 \%$ between $6-10$ years and $37.3 \% 11$ years or more. The distribution of parameters regarding how the faculties continue their theoretical, practical and clinical applications in the 2020 spring, 2020 autumn and 2021 spring terms of the pandemic was demonstrated in Table 1.

While the level of students' participation in online courses was very low in $4.5 \%$ of the faculties, it was found to be low in $6 \%$, moderate in $47.8 \%$, high in $31.3 \%$ and very high in $10.4 \%$. In response to the question "What level do you think the learning level of students is in online courses compared to face-to-face courses", $65.7 \%$ of the faculties reported that they were at medium level and $23.9 \%$ at low level. The distribution of the extra materials provided to clinical students for infection control and the precautions taken for clinical practice was demonstrated in Table 2. Accordingly, the majority of faculties $(72.5 \%)$ provided all personal protective equipment for infection control. In addition, most of the faculties reduced the number of patients treated in clinics $(80.4 \%)$ and the number of students in the internship group (86.3\%).

The distribution of the theoretical and practical course exams in the 2020 spring-autumn and 2021 spring terms was showed in 
Table 1. Distribution of parameters related to the method of continuing theoretical, preclinical and clinical education during the pandemic

\begin{tabular}{|c|c|c|c|}
\hline & & n & $\%$ \\
\hline \multirow{4}{*}{$\begin{array}{l}\text { The method of continuing theoretical education in the } 2020 \text { spring semester } \\
\text { of the pandemic }\end{array}$} & Online & 48 & 71.6 \\
\hline & With offline videos & 7 & 10.4 \\
\hline & With hybrid education & 5 & 7.5 \\
\hline & With lecture notes & 7 & 10.4 \\
\hline \multirow{4}{*}{$\begin{array}{l}\text { The method of continuing theoretical education in the } 2021 \text { spring semester } \\
\text { of the pandemic }\end{array}$} & Online & 48 & 71.6 \\
\hline & With offline videos & 2 & 3 \\
\hline & With hybrid education & 15 & 22.4 \\
\hline & With lecture notes & 2 & 3 \\
\hline \multirow[t]{2}{*}{ Presence of preclinical students } & Yes & 62 & 92.5 \\
\hline & No & 5 & 7.5 \\
\hline \multirow{5}{*}{$\begin{array}{l}\text { The method of continuing preclinical education in the } 2020 \text { spring semester of } \\
\text { the pandemic }(n=62)\end{array}$} & Face to face & 9 & 14.5 \\
\hline & Online & 25 & 40.3 \\
\hline & With videos & 11 & 17.7 \\
\hline & By giving homework & 8 & 12.9 \\
\hline & Other & 9 & 14.5 \\
\hline \multirow{5}{*}{$\begin{array}{l}\text { The method of continuing preclinical education in the } 2020 \text { autumn semester } \\
\text { of the pandemic ( } n=62 \text { ) }\end{array}$} & Face to face & 15 & 24.2 \\
\hline & Online & 28 & 45.2 \\
\hline & With videos & 8 & 12.9 \\
\hline & By giving homework & 7 & 11.3 \\
\hline & Other & 4 & 6.5 \\
\hline \multirow{5}{*}{$\begin{array}{l}\text { The method of continuing preclinical education in the } 2021 \text { spring semester of } \\
\text { the pandemic }(n=62)\end{array}$} & Face to face & 32 & 51.6 \\
\hline & Online & 19 & 30.6 \\
\hline & With videos & 7 & 11.3 \\
\hline & By giving homework & 1 & 1.6 \\
\hline & Other & 3 & 4.8 \\
\hline \multirow[t]{2}{*}{ Presence of clinical students } & Yes & 51 & 76.1 \\
\hline & No & 16 & 23.9 \\
\hline \multirow[t]{7}{*}{ Continuation of clinical internships in the 2020 spring pandemic period $(n=51)$} & Face to face & 8 & 15.7 \\
\hline & Postponed to autumn semester & 12 & 23.5 \\
\hline & Not done - online exam only & 18 & 35.3 \\
\hline & With videos & 3 & 5.9 \\
\hline & By giving homework & 1 & 2 \\
\hline & With case discussions & 4 & 7.8 \\
\hline & Other & 5 & 9.8 \\
\hline \multirow{6}{*}{$\begin{array}{l}\text { Continuation of clinical internships in the } 2020 \text { autumn pandemic period } \\
(n=51)\end{array}$} & Face to face & 25 & 49 \\
\hline & Postponed to spring semester & 11 & 21.6 \\
\hline & Not done - online exam only & 9 & 17.6 \\
\hline & With videos & 1 & 2 \\
\hline & By giving homework & 2 & 3.9 \\
\hline & With case discussions & 3 & 5.9 \\
\hline \multirow[t]{4}{*}{ Continuation of clinical internships in the 2021 spring pandemic period $(n=51)$} & Face to face & 45 & 88.2 \\
\hline & $\begin{array}{l}\text { Won't - only online exam will be } \\
\text { done }\end{array}$ & 4 & 7.8 \\
\hline & With case discussions & 1 & 2 \\
\hline & Other & 1 & 2 \\
\hline
\end{tabular}


Table 2. Distribution of the extra materials provided to clinical students for infection control and the precautions taken for the clinical practice

\begin{tabular}{|c|c|c|c|}
\hline & & $n$ & $\%$ \\
\hline \multirow{7}{*}{$\begin{array}{l}\text { Extra materials provided to clinical } \\
\text { students for infection control }(n=51)\end{array}$} & All personal protective equipment provided & 37 & 72.5 \\
\hline & N95 mask & 9 & 17.6 \\
\hline & Surgical gown or overalls & 8 & 15.7 \\
\hline & Visor & 2 & 3.9 \\
\hline & Bonnet & 13 & 25.5 \\
\hline & Surgical mask & 14 & 27.5 \\
\hline & Other materials & 2 & 3.9 \\
\hline \multirow{10}{*}{$\begin{array}{l}\text { Measures taken for the clinical practice } \\
(n=51)\end{array}$} & Teledentistry support & 6 & 11.8 \\
\hline & Creating a triage area & 24 & 47.1 \\
\hline & Areas with multiple units were dividing one by one. & 30 & 58.8 \\
\hline & Patients are seated in the units at intervals & 35 & 68.6 \\
\hline & Surgical suctions, double suction or special suction apparatus are used & 15 & 29.4 \\
\hline & Ventilation systems rearranged (hepafilter etc.) & 25 & 49.0 \\
\hline & The number of patients has been reduced & 41 & 80.4 \\
\hline & Appointment duration extended & 33 & 64.7 \\
\hline & The number of students in the internship group has been reduced & 44 & 86.3 \\
\hline & Internship time reduced & 26 & 51.0 \\
\hline
\end{tabular}

table 3. According to this, most of the faculties $(83.6 \%, 95.5 \%$, $77.6 \%$; respectively) conducted the theoretical exams online. On the other hand, half of the faculties (51.5\%) performed online the practical exams in the spring term of 2020 , while $43.3 \%$ performed face-to-face in the autumn term of 2020. In the spring term of 2021, $47.8 \%$ of the faculties reported that they performed practical exams face-to-face. While $4.5 \%$ of faculties believe that online exams measure students' knowledge correctly, $43.3 \%$ do not believe and $52.2 \%$ partially believe. In addition, $80.6 \%$ of the faculties reported that they took an extra precaution to prevent cheating in online exams, while $19.4 \%$ did not take extra precautions. The most frequently taken precautions include shortening the exam time (70.4\%), conducting multiple-choice exams $(66.7 \%)$, and setting time limits per question (53.7\%). While $47.8 \%$ of the faculties created a separate program for compensation of the missing education in the 2020 spring term, $52.2 \%$ did not create any program. In the trainings given during the pandemic period, attendance was mostly ignored (67.2\%) and the practical thresholds were lowered (61.2\%).

While $29.9 \%$ of the faculties consider using virtual reality devices for clinical and preclinical education, $23.9 \%$ do not

Table 3. Distribution of the methods of conducting the theoretical and practical course exams for 2020 and 2021

\begin{tabular}{|c|c|c|c|c|c|}
\hline & & \multicolumn{2}{|c|}{ University } & \multirow[b]{2}{*}{ Total } & \multirow{3}{*}{$\mathbf{p}$} \\
\hline & & State & Private & & \\
\hline & & $n(\%)$ & n (\%) & $n(\%)$ & \\
\hline \multirow{3}{*}{$\begin{array}{l}\text { The method of conducting the theoretical course exams in the } \\
\text { spring term of } 2020\end{array}$} & Face to face & $2(5 \%)$ & $1(3.7 \%)$ & $3(4.5 \%)$ & ${ }^{1} 0.010 *$ \\
\hline & Online & $37(92.5 \%)$ & $19(70.4 \%)$ & $56(83.6 \%)$ & \\
\hline & Other & $1(2.5 \%)$ & $7(25.9 \%)$ & $8(11.9 \%)$ & \\
\hline \multirow{2}{*}{$\begin{array}{l}\text { The method of conducting the theoretical course exams in the } \\
\text { autumn term of } 2020\end{array}$} & Face to face & $0(0 \%)$ & $3(11.1 \%)$ & $3(4.5 \%)$ & ${ }^{2} 0.061$ \\
\hline & Online & $40(100 \%)$ & $24(88.9 \%)$ & $64(95.5 \%)$ & \\
\hline \multirow{3}{*}{$\begin{array}{l}\text { The method of conducting the theoretical course exams in the } \\
\text { spring term of } 2021\end{array}$} & Face to face & $6(15 \%)$ & $3(11.1 \%)$ & $9(13.4 \%)$ & ${ }^{1} 0.108$ \\
\hline & Online & $33(82.5 \%)$ & $19(70.4 \%)$ & $52(77.6 \%)$ & \\
\hline & Other & $1(2.5 \%)$ & $5(18.5 \%)$ & $6(9 \%)$ & \\
\hline \multirow{4}{*}{$\begin{array}{l}\text { The method of conducting the practical course exams in the } \\
\text { autumn term of } 2020(n=66)\end{array}$} & Face to face & $4(10 \%)$ & $2(7.7 \%)$ & $6(9.1 \%)$ & ${ }^{1} 0.373$ \\
\hline & Online & $22(55 \%)$ & $12(46.2 \%)$ & 34 (51.5\%) & \\
\hline & Homework & $12(30 \%)$ & $7(26.9 \%)$ & $19(28.8 \%)$ & \\
\hline & Other & $2(5 \%)$ & $5(19.2 \%)$ & $7(10.6 \%)$ & \\
\hline \multirow{4}{*}{$\begin{array}{l}\text { The method of conducting the practical course exams in the spring } \\
\text { term of } 2020(n=66)\end{array}$} & Face to face & $5(12.5 \%)$ & $7(25.9 \%)$ & $12(17.9 \%)$ & ${ }^{1} 0.210$ \\
\hline & Online & $20(50 \%)$ & $9(33.3 \%)$ & $29(43.4 \%)$ & \\
\hline & Homework & $10(25 \%)$ & $10(37 \%)$ & $20(29.9 \%)$ & \\
\hline & Other & $5(12.5 \%)$ & $1(3.7 \%)$ & $6(9 \%)$ & \\
\hline \multirow{4}{*}{$\begin{array}{l}\text { The method of conducting the practical course exams in the spring } \\
\text { term of } 2021(n=66)\end{array}$} & Face to face & $19(47.5 \%)$ & $13(48.1 \%)$ & $32(47.8 \%)$ & ${ }^{1} 0.376$ \\
\hline & Online & $10(25 \%)$ & $4(14.8 \%)$ & $14(20.9 \%)$ & \\
\hline & Homework & $7(17.5 \%)$ & $9(33.3 \%)$ & $16(23.9 \%)$ & \\
\hline & Other & $4(10 \%)$ & $1(3.7 \%)$ & $5(7.5 \%)$ & \\
\hline
\end{tabular}


consider about it. The reason why are mostly due to high cost and lack of appropriate infrastructure.

While $50 \%$ of state universities continue education for 11 years or more, $51.9 \%$ of private universities provide education between $0-5$ years. The rate of continuing the theoretical education online (72.5\%) in the 2020 spring term of the pandemic of state universities was statistically higher than that of private universities $(70.4 \%)(p: 0.033 ; p<0.05)$. In the autumn of 2020 and spring of 2021, there was no significant difference between state and private universities $(p>0.05)$ (Table 4 ). There was no statistically significant difference between the ways in which state and private universities continued practical courses and clinical internships during the pandemic period ( $p>0.05)$.

Table 4. Evaluation of the parameters related to the method of continuing the theoretical education of the faculties during the pandemic according to the university

\begin{tabular}{|c|c|c|c|c|}
\hline & & \multicolumn{2}{|c|}{ University } & \multirow{3}{*}{$\mathbf{p}$} \\
\hline & & State & Private & \\
\hline & & $\mathrm{n}(\%)$ & $n(\%)$ & \\
\hline \multirow{4}{*}{$\begin{array}{l}\text { The method of } \\
\text { continuing theoretical } \\
\text { education in the } 2020 \\
\text { spring semester of the } \\
\text { pandemic }\end{array}$} & Online & $29(72.5 \%)$ & $\begin{array}{c}19 \\
(70.4 \%)\end{array}$ & $0.033^{*}$ \\
\hline & $\begin{array}{l}\text { With offline } \\
\text { videos }\end{array}$ & $6(15 \%)$ & $1(3.7 \%)$ & \\
\hline & $\begin{array}{l}\text { With hybrid } \\
\text { education }\end{array}$ & $4(10 \%)$ & $1(3.7 \%)$ & \\
\hline & $\begin{array}{l}\text { With lecture } \\
\text { notes }\end{array}$ & $1(2.5 \%)$ & $6(22.2 \%)$ & \\
\hline \multirow{4}{*}{$\begin{array}{l}\text { The method of } \\
\text { continuing theoretical } \\
\text { education in the } 2020 \\
\text { autumn semester of } \\
\text { the pandemic }\end{array}$} & Online & $32(80 \%)$ & $\begin{array}{c}16 \\
(59.3 \%)\end{array}$ & 0.099 \\
\hline & $\begin{array}{l}\text { With offline } \\
\text { videos }\end{array}$ & $2(5 \%)$ & $1(3.7 \%)$ & \\
\hline & $\begin{array}{l}\text { With hybrid } \\
\text { education }\end{array}$ & $6(15 \%)$ & $8(29.6 \%)$ & \\
\hline & $\begin{array}{l}\text { With lecture } \\
\text { notes }\end{array}$ & $0(0 \%)$ & $2(7.4 \%)$ & \\
\hline \multirow{4}{*}{$\begin{array}{l}\text { The method of } \\
\text { continuing theoretical } \\
\text { education in the } 2021 \\
\text { spring semester of the } \\
\text { pandemic }\end{array}$} & Online & 31 (77.5\%) & $17(63 \%)$ & 0.573 \\
\hline & $\begin{array}{l}\text { With offline } \\
\text { videos }\end{array}$ & $1(2.5 \%)$ & $1(3.7 \%)$ & \\
\hline & $\begin{array}{l}\text { With hybrid } \\
\text { education }\end{array}$ & $7(17.5 \%)$ & $8(29.6 \%)$ & \\
\hline & $\begin{array}{l}\text { With lecture } \\
\text { notes }\end{array}$ & $1(2.5 \%)$ & $1(3.7 \%)$ & \\
\hline
\end{tabular}

A comparison of the measures taken for clinical practice of the extra materials provided to clinical students for infection control by universities was showed in table 5 . Accordingly, the rate of providing all personal protective equipment to interns (84.8\%) by state universities was statistically significantly higher than private universities (50\%) ( $p: 0.019 ; p<0.05)$. In addition, the rate of providing students with bonnet (12.1\%) and surgical masks $(15.2 \%)$ was statistically lower in state universities $(p<0.05)$. While the areas with multiple units in state universities were mostly closed one by one (63.3\%), private universities preferred to use the units intermittently $(88.9 \%)$ and to renew their ventilation systems (72.2\%) (Table 5).

Table 5. Evaluation of the extra materials provided to clinical students for infection control and the precautions taken for the clinical practice according to the university

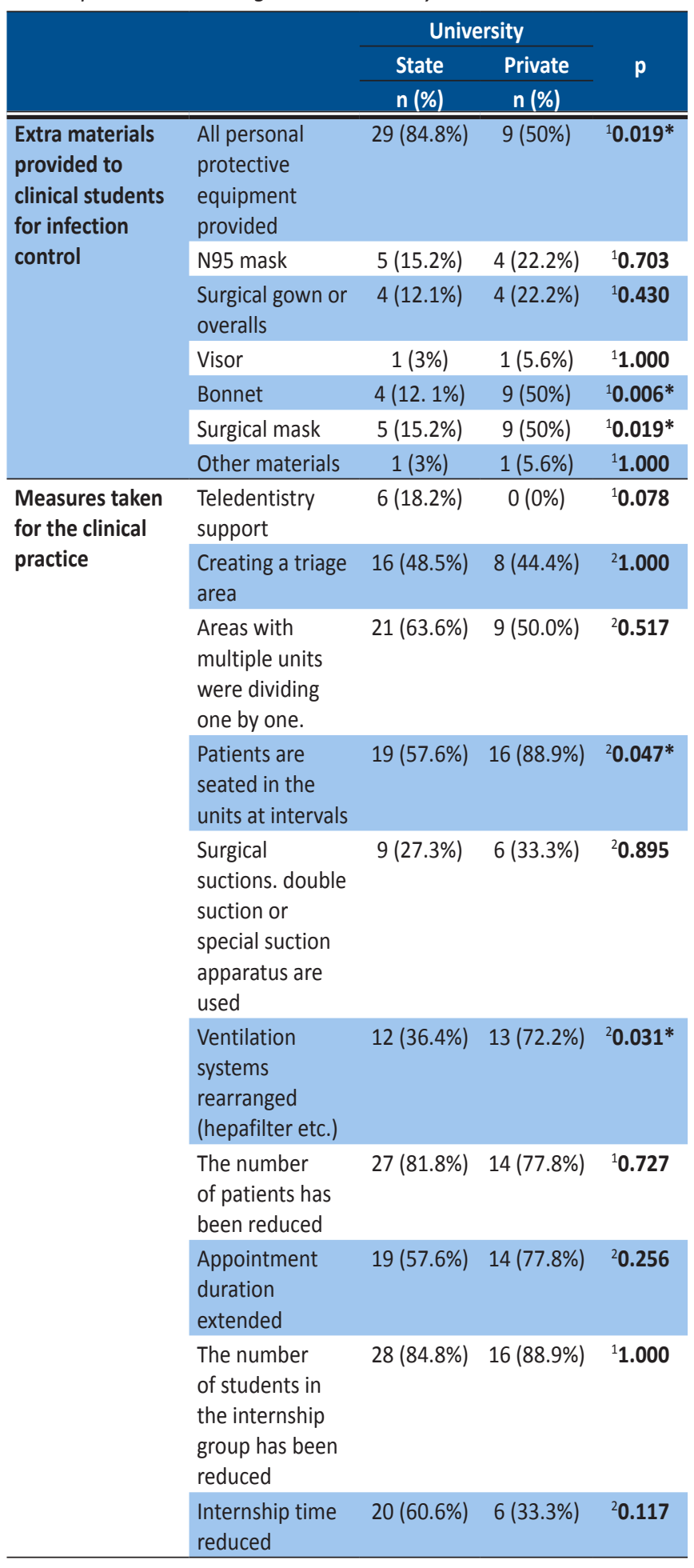

${ }^{1}$ Fisher's Exact Test $\quad{ }^{2}$ Continuity (Yates) Correction $\quad{ }^{*} p<0.05$

The rate of online theoretical course exams (92.5\%) in state universities in the spring term of 2020 was found to 
Table 6. Evaluation of the parameters related to the method of continuing the theoretical education of the faculties during the pandemic according to the education period of the faculties

\begin{tabular}{|c|c|c|c|c|c|}
\hline & & \multicolumn{3}{|c|}{ Faculty education period } & \multirow{3}{*}{$\mathbf{p}$} \\
\hline & & $0-5$ years & $6-10$ years & $\begin{array}{l}11 \text { years and } \\
\text { above }\end{array}$ & \\
\hline & & $\mathrm{n}(\%)$ & $\mathrm{n}(\%)$ & $\mathrm{n}(\%)$ & \\
\hline \multirow{4}{*}{$\begin{array}{l}\text { The method of continuing theoretical } \\
\text { education in the } 2020 \text { spring semester of the } \\
\text { pandemic }\end{array}$} & Online & $19(67.9 \%)$ & $10(71.4 \%)$ & $19(76 \%)$ & ${ }^{2} 0.001 *$ \\
\hline & With offline videos & $2(7.1 \%)$ & $4(28.6 \%)$ & $1(4 \%)$ & \\
\hline & With hybrid education & $0(0 \%)$ & $0(0 \%)$ & $5(20 \%)$ & \\
\hline & With lecture notes & $7(25 \%)$ & $0(0 \%)$ & $0(0 \%)$ & \\
\hline \multirow{4}{*}{$\begin{array}{l}\text { The method of continuing theoretical } \\
\text { education in the } 2020 \text { autumn semester of } \\
\text { the pandemic }\end{array}$} & Online & $19(67.9 \%)$ & $9(64.3 \%)$ & $20(80 \%)$ & 0.618 \\
\hline & With offline videos & $2(7.1 \%)$ & $1(7.1 \%)$ & $0(0 \%)$ & \\
\hline & With hybrid education & $7(25 \%)$ & $3(21.4 \%)$ & $4(16 \%)$ & \\
\hline & With lecture notes & $0(0 \%)$ & $1(7.1 \%)$ & $1(4 \%)$ & \\
\hline \multirow{4}{*}{$\begin{array}{l}\text { The method of continuing theoretical } \\
\text { education in the } 2021 \text { spring semester of the } \\
\text { pandemic }\end{array}$} & Online & $21(75 \%)$ & $9(64.3 \%)$ & $18(72 \%)$ & 0.492 \\
\hline & With offline videos & $1(3.6 \%)$ & $1(7.1 \%)$ & $0(0 \%)$ & \\
\hline & With hybrid education & $6(21.4 \%)$ & $4(28.6 \%)$ & $5(20 \%)$ & \\
\hline & With lecture notes & $0(0 \%)$ & $0(0 \%)$ & $2(8 \%)$ & \\
\hline \multirow[t]{2}{*}{ Presence of clinical students } & Yes & $25(89.3 \%)$ & $12(85.7 \%)$ & $25(100 \%)$ & ${ }^{1} 0.174$ \\
\hline & No & $3(10.7 \%)$ & $2(14.3 \%)$ & $0(0 \%)$ & \\
\hline \multirow{5}{*}{$\begin{array}{l}\text { Continuation of clinical internships in the } \\
2020 \text { spring pandemic period }(n=51)\end{array}$} & Face to face & $5(20 \%)$ & $1(8.3 \%)$ & $3(12 \%)$ & ${ }^{2} 0.045 *$ \\
\hline & Postponed to autumn semester & $8(32 \%)$ & $6(50 \%)$ & $11(44 \%)$ & \\
\hline & Not done - online exam only & $1(4 \%)$ & $3(25 \%)$ & $7(28 \%)$ & \\
\hline & With videos & $3(12 \%)$ & $1(8.3 \%)$ & $4(16 \%)$ & \\
\hline & By giving homework & $8(32 \%)$ & $1(8.3 \%)$ & $0(0 \%)$ & \\
\hline \multirow{5}{*}{$\begin{array}{l}\text { Continuation of clinical internships in the } \\
2020 \text { autumn pandemic period }(n=51)\end{array}$} & With case discussions & $1(4 \%)$ & $7(58.3 \%)$ & $7(28 \%)$ & ${ }^{2} 0.040 *$ \\
\hline & Other & $14(56 \%)$ & $2(16.7 \%)$ & $12(48 \%)$ & \\
\hline & Face to face & $4(16 \%)$ & $1(8.3 \%)$ & $3(12 \%)$ & \\
\hline & Postponed to spring semester & $3(12 \%)$ & $2(16.7 \%)$ & $2(8 \%)$ & \\
\hline & Not done - online exam only & $3(12 \%)$ & $0(0 \%)$ & $1(4 \%)$ & \\
\hline \multirow{5}{*}{$\begin{array}{l}\text { Continuation of clinical internships in the } \\
2021 \text { spring pandemic period }(n=51)\end{array}$} & With videos & $8(32 \%)$ & $9(75 \%)$ & $15(60 \%)$ & ${ }^{2} 0.132$ \\
\hline & By giving homework & $10(40 \%)$ & $3(25 \%)$ & $6(24 \%)$ & \\
\hline & With case discussions & $3(12 \%)$ & $0(0 \%)$ & $4(16 \%)$ & \\
\hline & Face to face & $1(4 \%)$ & $0(0 \%)$ & $0(0 \%)$ & \\
\hline & Won't - only online exam will be done & $3(12 \%)$ & $0(0 \%)$ & $0(0 \%)$ & \\
\hline
\end{tabular}

be statistically significantly higher than private universities (70.4\%) ( $p: 0.010 ; p<0.05)$. Alternatively, private universities gave homework instead of exams. On the other hand, the rate of believing that online exams accurately measure students' knowledge in state universities $(0 \%)$ was statistically lower than that of private universities (11.1\%) ( $p: 0.032 ; p<0.05)$. However, there is no difference between universities in terms of precautions taken for exam security.

The evaluation of the parameters related to the theoretical and practical education continuation during the pandemic according to the education duration of the faculties was given in Table 6. The rate of continuing the theoretical education online $(67.9 \%)$ in the 2020 spring term of the pandemic of the faculties with education duration between $0-5$ years was found to be statistically significantly lower than the other groups $(p<0.05)$.

\section{DISCUSSION}

Covid-19 pandemic has adversely affected every field of life all over the world; but the largest impact was seen in the field of education (11). With the beginning of the pandemic, almost all faculties have been start to distance education instead of face-to-face training. Especially the faculties, which has practical training, were more affected by this situation $(12,13)$. Dental education is a training, in which theoretical information has been supported by practical training. According to the results of this study, dentistry faculties in our country continued online education in theoretical courses during the three terms of the pandemic. But they have preferred to return to face-to-face education for preclinical and clinical trainings together with the initiation of vaccination and providing protective equipment.

Dental education consists of 3 parts. The first part is theoretical lectures and are very easy to adapt to the distance education 
model. The latter is preclinical education (simulation laboratory courses). In this training, students work on the models and the instructor controls each stage. The distance education alternative to this part can only be with videos or virtual reality devices. When the time and human power required for this training is considered, it is very difficult to teach preclinical training online (6). In addition, according to the results of our study, many faculties do not have the grant and infrastructure for virtual reality devices. The third part is the clinical practice. In the clinical practice, students treat real patients and no alternative methods, including haptic devices, cannot fully meet this training. For this reason, the last part is the most difficult part of dental education to deal with pandemic environment (2).

With the onset of the Covid-19 pandemic, dentistry has been reported to be the most risky profession, and practical dental education has been suspended almost all over the world (14). Educational alternatives have been started to be considered in order to continue the education process, to enable students to gain the necessary competence, but also to protect them from the virus. As an alternative to direct learning strategies, most dental schools have adopted distance education strategies such as online courses and lectures, case discussions and webinars (13). According to the results of this study, depending on the decision of CoHE, all lectures were given online in the spring 2020 in our country, and it was thought as an alternative that the clinical trainings could be postponed until after the pandemic. Some universities, on the other hand, have made online case discussions instead of clinical practice. This result is in agreement with studies conducted in Europe, America, Pakistan, Saudi Arabia and Asia-pacific countries $(2,6,8,13,15)$. In China, where the pandemic emerged, $97 \%$ of dentistry faculties switched to online education during the pandemic, and less online education was preferred for practical training (16). Similarly, $71.6 \%$ of the universities in our country preferred online education for theoretical courses in the spring term of 2020. Preclinical education was conducted online at a lower rate (40.3\%), while clinical education was either not done (35\%) or postponed (23\%). In many studies in the literature, the authors agree that providing preclinical and clinical education by distance education method or virtual reality systems cannot replace face-to-face education $(13,16)$.

In the autumn 2020, CoHE gave the initiative regarding education model during the pandemic to universities (17). Considering that the pandemic will last longer, it has emerged that education in dentistry faculties should continue and it will not be possible to graduate for students who do not clinical practice (8). For this reason, the universities aimed to create an environment that provides safety for students, faculty members and staff and to continue their preclinical and clinical training. The results of the present study demonstrated, clinical practice, which was mostly concluded with online exams in the spring 2020 (35.3\%), continued by face-to-face training in the autumn of 2020 (49\%). Similar results are obtained for preclinical training. In line with our country, a concept that returns to "face-to-face" training has started in Germany in July 2020, despite the COVID-19 pandemic (18). According to the results of the present study, more than half of the faculties have provided all the protective equipment to the students in order to return face-to-face training. In addition, the vast majority of them restored the multi-units open clinics in a way that divided the units, and made adjustments to the appointment durations, daily number of patients and ventilation systems. The state's inclusion of all practicing students in the vaccination program has also been very effective in returning to face-to-face education.

The academicians participating in this study stated that the learning level of the students with online education was moderate $(65.7 \%)$ and less $(23.9 \%)$ compared to face-toface education. Similarly, in many studies in the literature, students reported that the efficiency they received from online lectures was less than face-to-face education $(12,15)$. In addition, students stated that they wanted to continue face-to-face education especially for practical courses after the pandemic and that distance education can only be considered as a complement to traditional education methods $(11,15,18)$. In studies conducted in Germany and Turkey, the majority of both, students and educators, reported that they preferred the hybrid education model in which distance education continues to a certain extent in the future. In our country, many universities still continue their education with a hybrid education model. Again, in these studies, students wanted clinical practice to be supported by detecting their deficiencies during the pandemic period $(12,18)$. This deficiency has been tried to be eliminated with case discussions in our country, and $7.8 \%$ of universities continued their clinical education with this education method during the pandemic. Although case discussions are helpful in adaptation theoretical knowledge to practice, it is not a substitute for clinical experience. Additional training such as courses for new graduates should be given in order to eliminate the clinical deficiencies. As a matter of fact, nearly half of the faculties (47.8\%) have created an additional program to make up for the missing education in the 2020 spring term.

Updates had to be made not only in education methods but also in assessment and evaluation systems. In the study of Hardy et al. (13), academicians stated that the most appropriate preclinical exam technique is to conduct virtual exams in simulation laboratories (39.3\%) and postpone exams until after the pandemic (24.6\%). For clinical practice, they suggested postpone the exams (22.1\%). Contrary to this result, online exams (51.1\%) and homework (28.8\%) were preferred for preclinical education in our country. It is thought that the practical deficiencies of the students will be covered with the compensation programs (47.8\%) to be made later. However, the faculties preferred to postpone (23.5\%) the education for clinical practice. Universities in Europe have planned to extend internship periods instead of reducing the clinical requirements in order to graduate (8). In the present study, reducing the clinical requirements (61.2\%) was preferred rather than extending the internship 
period (4.5\%). Additionally, nearly half of the faculties in our study did not believe that online exams measure knowledge correctly, and $80.6 \%$ of them had to take extra precautions such as time restrictions and log records to avoid cheating. Because audit mechanisms are weak in online exams. A special online exam platform may also need to be developed for the reliability of online exams in dental education in the future.

In this study, the education methods of state and private universities during the pandemic period were compared. Only in the spring term of 2020 (in the first period of the pandemic), the rate of continuing theoretical education online in state universities was found to be higher than in private universities. However, private universities quickly completed their deficiencies (distance education platform, online course materials, etc.) and there was no significant difference between universities in terms of coursework in other terms. Contrary to this study, it was reported that state schools in Pakistan were less successful than private schools in distance education (15). In addition, this study demonstrated that the rate of continuing theoretical education online in the spring 2020 of the faculties with a education period between 0-5 years was found to be lower than other groups. They continued their education mainly with lecture notes. The reason for this can be interpreted as the fact that the new faculties do not have the distance education infrastructure and sufficient faculty members to cope with this extraordinary situation. When examined in terms of clinical practice, in this study, the rate of providing all personal protective equipment to clinical internship students of state universities was found to be higher than private universities. It has been observed that state universities can obtain protective equipment faster with the support of the state, while private universities demand that some of the protective equipment be covered by the students. In a study in which many countries from Europe, America, Asia and Africa participated, only $44 \%$ of academicians said that they could access N95 masks (19). According to the results of this study, we can assume that the rate of access to personal protective equipment is much higher in our country $(72.5 \%)$.

Despite all these findings, it is possible to say that the pandemic has pros as well as cons. Although the prepandemic distance education model started slowly in some countries, it was rarely used especially in the field of dentistry (13). However, with the pandemic, the hybrid education model, in which the theoretical courses are given with distance education and the practical courses are theach face-to-face in dental education, has been adopted by both educators and students. Therefore, we can state that our hypothesis was confirmed. In addition, work on modern virtual simulation devices, haptic technologies, and the use of artificial intelligence in dental education has accelerated, but needs further development.

There are limitions of the present study. First, due to the cross-sectional design of this study, the educational methods of universities were recorded over a period of time, and changes may have occurred in the methods of some institutions after data collection. Second, all dentistry faculties in Turkey could not be reached. Long-term studies including several dentistry faculties from different countries are needed in the literature.

\section{CONCLUSION}

Distance education model was preferred for theoretical courses in our country during the Covid-19 pandemic. However, it was more preferred to return to traditional methods in practical training. The hybrid education model, which has just entered our lives in the field of dentistry, is used in almost all universities. All faculties that include practical courses, such as dentistry faculties, should accept this pandemic as an opportunity, share their experiences in this process, identify their deficiencies, and develop appropriate education policies that include distance education model permanently against possible future pandemics.

\section{Funding}

No funding was received.

\section{Conflicts of interest}

The authors have no conflict of interest to disclose.

\section{REFERENCES}

[1] Timeline of WHO's response to COVID-19. World Health Organization. Available from: https://www.who.int/ emergencies/diseases/novel-coronavirus-2019/interactivetimeline\#! accessed on 24 September 2020).

[2] Chang T, Hong G, Paganelli C, Phantumvanit P, Chang W, Shieh $\mathrm{Y}$, Hsu M. Innovation of dental education during COVID-19 pandemic. J Dent Sci 2021;16(1):15-20.

[3] Yükseköğretim kurulu (YÖK) basın açıklaması (2020). Available from: https://www.yok.gov.tr/Sayfalar/ Haberler/2020/YKS\%20Ertelenmesi\%20Bas\%C4\%B1n\%20 A\%C3\%A7\%C4\%B1klamas\%C4\%B1.aspx (accessed on 9 August 2021).

[4] Emami E. COVID-19: Perspective of a dean of dentistry. JDR Clin Trans Res 2020;5(3):211-213.

[5] Machado RA, Bonan PRF, Perez DEDC, Martelli JÚnior H. COVID-19 pandemic and the impact on dental education: Discussing current and future perspectives. Braz Oral Res 2020;Jun 29. 34:e083. doi: 10.1590/1807-3107bor-2020.

[6] Iyer P, Aziz K, Ojcius DM. Impact of COVID-19 on dental education in the United States. J Dent Educ 2020;84(6):718722.

[7] Sukumar S, Dracopoulos SA, Martin FE. Dental education in the time of SARS-CoV-2. Eur J Dent Educ 2020;25(2):325-331.

[8] Quinn B, Field J, Gorter R, Akota I, Manzanares MC, Paganelli C, Daviers J, Dixon J, Gabor G, Mendes RA, Hahn P, Vital S, O'Brien J, Murphy D, Tubert-Jeannin S. COVID-19: The immediate response of european academic dental institutions and future implications for dental education. Eur J Dent Educ 2020;24(4):811-814. 
[9] Santos GNM, Leite AF, Figueiredo PTS, Pimentel NM, FloresMir C, de Melo NS, Guerra ENS, Canto GDL. Effectiveness of e-learning in oral radiology education: A systematic review. J Dent Educ 2016;80(9):1126-1139.

[10] Telli SG, Altun D. Coronavirüs ve çevrimiçi (online) eğitimin önlenemeyen yükselişi. Uni Ar Derg 2020;3(1):25-34.(Turkish)

[11] Senol D, Toy S, Canbolat M, Pektas M. Evaluation of online anatomy education given in medicine and dentistry faculties of universities during Covid-19 pandemic with student. Konuralp Med J 2021;13(1): 30-35.

[12] Demirel A, Önder NS, Topaloğlu P, Sarı Ş. Effects of Covid-19 pandemic on postgraduate education in pediatric dentistry: A survey study. Selcuk Dent J 2021;8:163-172.

[13] Haridy R, Abdalla MA, Kaisarly D, El Gezawi M. A crosssectional multicenter survey on the future of dental education in the era of COVID-19: Alternatives and implications. J Dent Educ 2021;85(4):483-493.

[14] Gamio L. The workers who face the greatest coronavirus risk. The New York Times. 2020 Mar 15 [cited 2020 Mar 15]. Available from: https://www.nytimes.com/interactive/2020/03/15/ business/economy/coronavirus-worker risk. html?action=click\&module=Top+Stories\&pgtype=Homepage

[15] Sarwar H, Akhtar H, Naeem MM, Khan JA, Waraich K, Shabbir S, Hasan A, Khursid Z. Self-reported effectiveness of e-learning classes during COVID-19 pandemic: A nation-wide survey of pakistani undergraduate dentistry students. Eur J Dent 2020;14(S01):34-43.

[16] Wang K, Zhang L, Ye L. A nationwide survey of online teaching strategies in dental education in China. J Dent Educ 2021;85(2):128-134.

[17] Yükseköğretim kurumlarımızdaki 2020-2021 eğitim ve öğretim dönemine yönelik açıklama-13.8.2020. Yükseköğretim kurulu (YÖK). Available from: https://covid19.yok.gov.tr/alinankararlar (accessed on 9 August 2021).(Turkish)

[18] Schlenz MA, Schmidt A, Wöstmann B, Kramer N, SchulzWeidner N. Students' and lecturers' perspective on the implementation of online learning in dental education due to SARS-CoV-2 (COVID-19): A cross-sectional study. BMC Med Educ 2020;20(1):354.

[19] Ammar N, Aly NM, Folayan MO, Khader Y, Mohebbi SZ, Attia S, Howaldt HP, Boettger S, Virtanen J, Madi M, Maharani DA, Rahardjo A, Khan I, Al-Batayneh OB, Rashwan M, Pavlic V, Cicmil S, Noritake K, Galluccio G, Polimeni A, Shamala AA, Aarheiam A, Mancino D, Phantumvanit P, Kim JB, Choi YH, Dama MA, Abdelsalam MM, Castillo JL, Nyan M, Hussein I, Joury E, Vukovic AP, landolo A, Kemoli AM, Tantawi ME. Perceived preparedness of dental academic institutions to cope with the COVID-19 pandemic: A multi-country survey. Int J Environ Res Public Health 2021;18(4):1445.

How to cite this article: Sirinoglu Capan B., Sezgin GP. Evaluation of the Effect of the Covid-19 Pandemic on the Education Process of Dentistry Faculties in Turkey: A Survey Study. Clin Exp Health Sci 2021; 11: 825-833. DOI: 10.33808/clinexphealthsci.966158 